\title{
Dispersal of individuals of the flightless grassland ground beetle, Carabus hungaricus (Coleoptera: Carabidae), in three populations and what they tell us about mobility estimates based on mark-recapture
}

\author{
Zoltan ELEK ${ }^{1}$, LuKÁš DRAG ${ }^{2,3}$, PAVEl POKLUDA ${ }^{2,3, *}$, LuKÁš ČÍŽEKEK ${ }^{2,3}$ and SÁNDor BÉRCES ${ }^{4}$ \\ ${ }^{1}$ MTA-ELTE-MTM Ecology Research Group, Hungarian Academy of Sciences, c/o Biological Institute of Eötvös Loránd University, \\ Pázmány Péter sétány 1/C., H-1117 Budapest, and Hungarian Natural History Museum, Baross u. 13., H-1088 Budapest, Hungary; \\ e-mail: zoltan.elek2@gmail.com \\ ${ }^{2}$ Faculty of Science, University of South Bohemia, Ceske Budejovice, Czech Republic \\ ${ }^{3}$ Institute of Entomology, Biology Centre, Academy of Sciences of the Czech Republic, Branisovska 31, 37005 Ceske Budejovice, \\ Czech Republic; e-mails: lukascizek@gmail.com; lukasdrag@gmail.com \\ ${ }^{4}$ Duna-Ipoly National Park Directorate, Budapest, Hungary, e-mail: bercess@gmail.com
}

Key words. Coleoptera, Carabidae, Carabus hungaricus, dispersal, inverse power function, Hungary, Czech Republic, Natura 2000

\begin{abstract}
Knowledge of the dispersal ability of endangered species is crucial for developing effective, evidence-based conservation policies. Due to their limited dispersal abilities and specific habitat requirements, insects are among the animals most threatened by habitat fragmentation. We studied three populations of the highly endangered species of ground beetle, Carabus hungaricus, at three sites in Central Europe (Hungary and Czech Republic) using mark-release-recapture (MRR). The total catch of 574 pitfall traps set at the three sites was 6255 individuals. Depending on the site, the percentage recaptured was $13-32 \%$. Average and maximum distance moved by individuals of both sexes at each of the sites ranged between 47-132 and 207-1104 m, respectively. The probability of the movements following an inverse power function (IPF) for the two sexes did not differ, but did differ among sites. Probability of dispersing for distances $>100 \mathrm{~m}$ differed by an order of magnitude between sites, most likely because of differences in how the samples were collected. Despite the fact that individual beetles are able to move over distances in the order of kilometres, the high fragmentation of their habitats is likely to prevent them from colonizing most uninhabited habitat patches. Therefore, the conservation of this threatened ground beetle could be improved by adopting and implementing a policy of assisted dispersal. Our results from three study sites also provide an interesting illustration of the variability in the estimates of the probability of dispersal obtained using MRR.
\end{abstract}

\section{INTRODUCTION}

Animal dispersal is a crucial biological trait that allows individuals to colonise new habitats, locate mating partners, food and other resources (Clobert et al., 2004; Bowler $\&$ Benton, 2005). Due to combination of their limited dispersal abilities and specific habitat requirements, insects are among the animals most threatened by habitat fragmentation (Ewers \& Didham, 2005). Increasing interest in biodiversity conservation, i.e. safeguarding occurrence of species in a fragmented landscape (e.g. Petit et al., 2001) requires also knowledge on their dispersal abilities. Improved analytical tools allow to study the dispersal of various model organisms (Petit et al., 2001; Ulrich \& Zalewski, 2007) in different landscapes (Van Dyck \& Baguette, 2005; Bonte et al., 2006; Sander et al., 2006; Campagne et al., 2009). Despite the advances, the questions most frequently asked by conservationists remain simple: what is the probability for an average individual to cross a given distance, and what is the range of maximum distances that individuals from a given population may realistically cover. The answers are highly important for delimitation of conservation areas, or for deciding between reintroduction and rely- ing on spontaneous colonisation in restoration programmes (e.g. Schultz, 1998; Maes et al., 2004).

Mark-release-recapture (MRR) data and regression models based on them are among the most common tools used to estimate animal dispersal (e.g. Hill et al., 1996; Fric \& Konvicka, 2007; Zimmermann et al., 2011). Compared to other methods, such as population genetic analyses, telemetry, and dispersal simulators (i.e. flight-mills), the MRRbased results tend to give lowest dispersal estimates due to underestimation of long-distance movements (Koenig et al., 1996; Jonsell et al., 2003; Drag et al., 2011; Chiari et al., 2013; David et al., 2013; Oleksa et al., 2013), and vary due to local conditions and/or sampling designs (e.g. Stevens et al., 2010; Hassal \& Thompson, 2012). However little is known how MRR-based estimates of a species mobility vary due to local conditions or sampling designs for ground beetles as one of the important model groups in terrestrial ecology (Thiele, 1977).

The ground beetle Carabus (Pachystus) hungaricus hungaricus (Fabricius, 1792) (Coleoptera: Carabidae) inhabits dry calcareous, loess, and sand grasslands from lowlands up to nearly $600 \mathrm{~m}$ a.s.l. in the Carpathian Basin (Hůrka, 1996; Bérces et al., 2008). The species is globally declin-

\footnotetext{
* Deceased.
} 
ing, protected and/or red-listed in most countries of occurrence, listed also in Annexes II and IV of the EU Habitats Directive (e.g. Szél et al., 2006; Bérces et al., 2008). As a typical steppe species, the ground beetle Carabus hungaricus represents Pannonian steppe invertebrates (e.g. Cizek et al., 2012) in EU legislation. Despite previous investigations, no information on mobility of this species has been published.

In this paper, we investigate mobility patterns in three populations of the flightless, protected grassland specialist ground beetle, Carabus hungaricus (Coleoptera: Carabidae). We applied the power law function to obtain movement parameters. We will discuss how the sampling design may affect these estimates based on power law function. The variability in those estimates provides an interesting illustration of reliability and comparability of the MMR based dispersal estimates in ground beetles.

\section{MATERIAL AND METHODS}

\section{Sampling sites and sampling design}

The beetles were sampled at three locations (Fig. 1), including (i) Pouzdrany steppe, and (ii) Tabulova in southern Moravia (Czech Republic), and (iii) Szentendre island near Budapest (Hungary). At each site, beetles were individually marked by numbers or codes engraved on their elytra; after marking, they were released immediately.

Ad (i), the locality is protected as National Nature Reserve and Site of Community Importance (total area: 180.8 ha, 200-300 m a.s.l.), with $C$. hungaricus as one of its target species. It represents one of the largest remnants of subcontinental steppic grasslands in the region. It is partly overgrown with shrubs and trees due to abandonment and hands-off conservation approach. Active management, consisting of grazing and mowing, was partly reestablished after 1989. 204 live-capture pitfall traps were positioned across the steppe and its vicinity, distributed at various distances. The minimum distance between neighbouring traps was $5 \mathrm{~m}$. Sampling focused on grasslands, but covered a wide range of habitats and vegetation types. Sampling took place from 26.3.-6.11.2006. See Table 1 and Pokluda et al. (2012) for details.

Ad (ii), the locality is part of Pálava Protected Landscape Area, and Stolová hora Site of Community Importance (total area: 77.1 ha, 380-450 m a.s.1.), covered by remnants of subcontinental, calcareous steppic grasslands on limestone. 100 live-capture pitfall traps were positioned across steppe at various distances. The minimum distance between neighbouring traps was $5 \mathrm{~m}$. Sam-

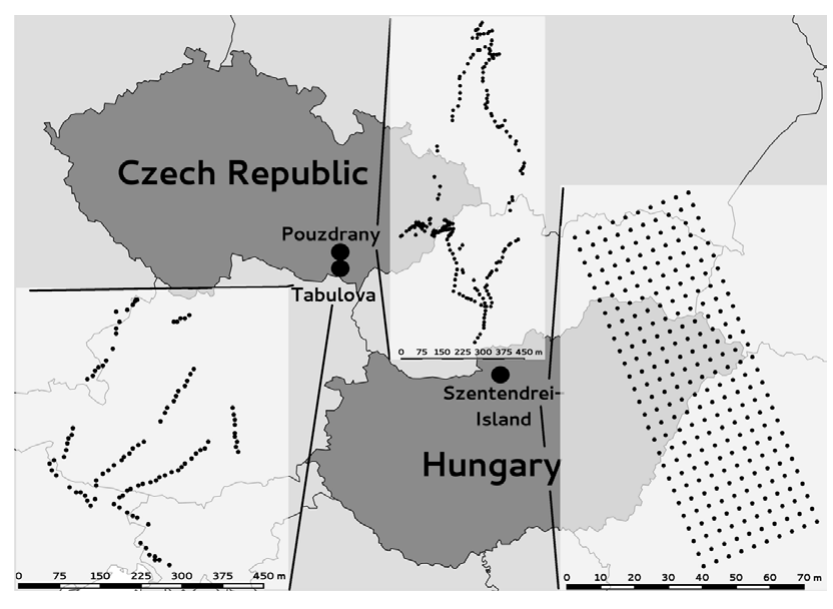

Fig. 1. Pattern of the distributions of the pitfall traps used in the three areas in the Czech Republic and Hungary where the dispersal of the ground beetle, Carabus hungaricus (Coleoptera: Carabidae), was studied using mark-recapture.

pling focused on grasslands and took place from 2.9.-19.10.2008. (Table 1).

Ad (iii), the locality is an island in the Danube River with three sand dune areas, all belonging to the authority of the Duna-Ipoly National Park. It is a Site of Community Importance with the appellation of "HUDI20047 Szigeti homokok". Area near the village of Pócsmegyer (about 170 ha, 100-120 m a.s.l.) comprising 40 ha is covered with tall-grass vegetation of the Pannonian sand steppes (Festucetum vaginatae) and was selected as the study site. These grasslands are fragmented by patches of black locust plantations (Robinia pseudoacacia). 270 non-baited pitfall traps were placed in a $4 \times 4 \mathrm{~m}$ grid in 10 rows and 27 columns, covering an area of 0.4 ha. Sampling focused on grasslands and took place from 9.5.-28.10.2008. See Table 1 and Bérces \& Elek (2013) for details.

\section{Data analysis}

For dispersal analyses, straight distances between capture points (traps) were summed to obtain the movements for each beetle recaptured at least once. Based on these distances, we computed for each sex and site the inverse power function (IPF), expressing the probability density $I$ of movements to distances $D$ :

$$
I \sim C \times D^{n}
$$

The function is fitted by plotting the logarithm of cumulative fractions of individuals moving specific or greater distances $(\ln I)$ against linearized expressions of the distances, i.e., $\ln I=\ln C-$ $\mathrm{n}(\ln D)$ (Hill et al., 1996; Fric \& Konvicka, 2007). Parameter $n$,

TABLE 1. Basic information on the sampling method and results of three mark-recapture studies on the ground beetle, Carabus hungaricus (Coleoptera: Carabidae) carried out at three sites in the Czech Republic and Hungary. M - male; F - female.

\begin{tabular}{|c|c|c|c|c|c|c|c|c|c|c|}
\hline Site & $\begin{array}{l}\text { Marking } \\
\text { period }\end{array}$ & $\begin{array}{l}\text { Span } \\
\text { (days) }\end{array}$ & $\begin{array}{c}\text { Search } \\
\text { days }\end{array}$ & $\begin{array}{l}\text { Number } \\
\text { of traps }\end{array}$ & $\begin{array}{l}\text { Mean (max.) dis- } \\
\text { tance between two } \\
\text { traps (in } \mathrm{m} \text { ) }\end{array}$ & Sex & $\begin{array}{c}\text { Marked } \\
\text { individuals }\end{array}$ & $\begin{array}{l}\text { Recaptured } \\
\text { individuals }\end{array}$ & $\begin{array}{l}\text { Mean distance } \\
\text { (m) (SD) }\end{array}$ & $\begin{array}{l}\text { Max. dis- } \\
\text { tance (m) }\end{array}$ \\
\hline \multirow{3}{*}{$\begin{array}{l}\text { Pouzdrany } \\
(\mathrm{CZ})\end{array}$} & $26.3-6.11 .2006$ & 204 & 67 & 204 & $508(1304)$ & $\mathrm{M}+\mathrm{F}$ & 3860 & 589 & & \\
\hline & & & & & & M & 1803 & 285 & $115.5(135.5)$ & 919 \\
\hline & & & & & & F & 2057 & 304 & $132.5(147.5)$ & 1104 \\
\hline \multirow{3}{*}{$\begin{array}{l}\text { Tabulova } \\
(\mathrm{CZ})\end{array}$} & 2.9.-19.10.2008 & 47 & 22 & 100 & $194(489)$ & $\mathrm{M}+\mathrm{F}$ & 1089 & 137 & & \\
\hline & & & & & & M & 555 & 67 & $51.4(62.2)$ & 287 \\
\hline & & & & & & $\mathrm{F}$ & 534 & 70 & $82.8(76.5)$ & 321 \\
\hline \multirow{3}{*}{$\begin{array}{l}\text { Szentendre } \\
(\mathrm{HU})\end{array}$} & 9.5.-28.10.2008 & 172 & 28 & 270 & $41(110)$ & $\mathrm{M}+\mathrm{F}$ & 1306 & 421 & & \\
\hline & & & & & & M & 717 & 257 & 47.5 (33.9) & 189 \\
\hline & & & & & & $\mathrm{F}$ & 589 & 164 & $47.1(32.8)$ & 207 \\
\hline
\end{tabular}




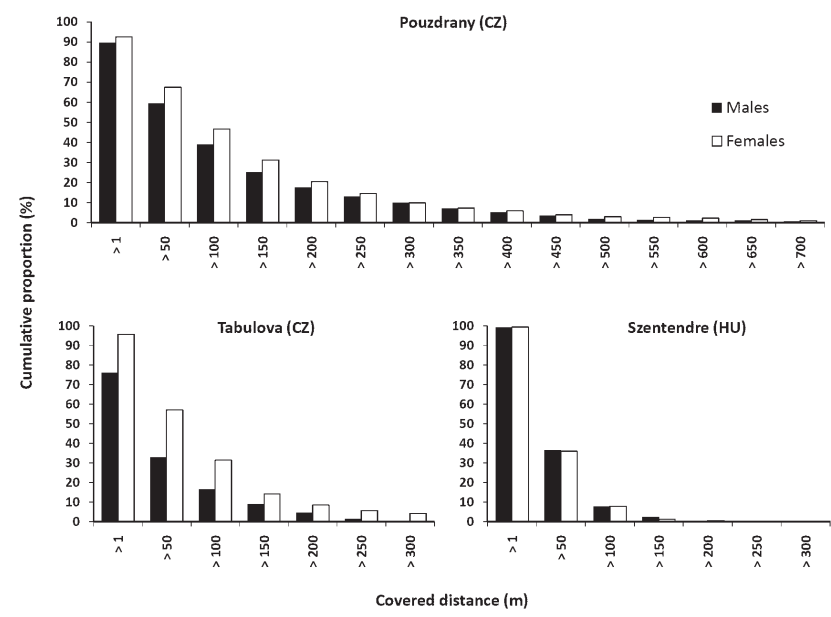

Fig. 2. The cumulative percentages of individuals of the ground beetle, Carabus hungaricus (Coleoptera: Carabidae) that dispersed over particular distances at the three sites studied in the Czech Republic (CZ) and Hungary (HU). Distances of $0 \mathrm{~m}$ (recaptured by the same trap) were excluded and the rest were divided into $50 \mathrm{~m}$ classes.

the slope of the linearized function, expresses the relative dispersal propensity, so that the shallower the slope, the higher possibility of long-distance dispersal (Baguette et al., 2000; Baguette, 2003). We carried out these regression models to obtain predictions of movements over long distances $(50,100,200,500$ and $1000 \mathrm{~m}$ ) for males and females separately and for both sexes together at each study site. The Tukey HSD tests were used to compare slopes and intercepts (= elevation) of the resulting linear regressions of males and females within each site and to compare movements of pooled sexes among different sites.

To compute daily movement, we divided the total covered distance by an individual by the number of days between the first and last catch. Individuals with long lifespan may cover large distances but then fell into a trap close to previous capture. To minimise such bias caused by MRR, only data from period with clear positive relation between lifespan and distance covered were used. The analyses were carried out in R 3.0.1 ( $\mathrm{R}$ core team 2013).

\section{RESULTS}

\section{Major movement patterns}

In Pouzdrany, out of the 3860 individuals marked (1803 males and 2057 females), 589 were recaptured (285 males and 304 females), and 536 (255 males, 281 females) moved to another trap. The average distance of $115.5 \mathrm{~m}$ and 132.5 $\mathrm{m}$ was crossed by males and by females respectively. The maximum recorded distance of movement was $919 \mathrm{~m}$ for male and $1104 \mathrm{~m}$ for male and female.

In Tabulova site, 1089 individuals (555 males and 534 females) were marked, 67 males and 70 females were recaptured, and 51 males and 67 females moved to another trap. The average distance taken by males and females were $51.5 \mathrm{~m}$ and $83 \mathrm{~m}$. The maximum recorded distance of movement was $287 \mathrm{~m}$ for male and $321 \mathrm{~m}$ for female.

In Szentendre, 1306 individuals (717 males and 589 females) were marked, 257 males and 164 females were recaptured at least once. 255 males and 163 females moved to another trap. The average distances taken by males and females were almost identical $47.5 \mathrm{~m}$ and $47 \mathrm{~m}$ respectively. The maximum distance taken was $189 \mathrm{~m}$ for males and $207 \mathrm{~m}$ for female (see Table 1 for further details).

\section{Movement models}

The estimates of movements, obtained from the IPF regressions, differed among the three study sites (Table 2 and Fig. 2). The lowest estimate of movement at the shortest calculated distance $(50 \mathrm{~m})$ was found in Szentendre (22.9\% of all individuals) while the highest estimate at the same distance was in Pouzdrany (86.8\%). Dispersal estimate for the longest calculated distance $(1000 \mathrm{~m})$ was $1.2 \%$ of all individuals in Pouzdrany, but only $0.1 \%$ of all individuals in Szentendre. The estimates of beetle movements at the third studied site, in Tabulova, were in between (41\% for $50 \mathrm{~m}, 0.9 \%$ pre $1000 \mathrm{~m}$ ) Based on the multiple comparisons of each site in the slope and elevation of IPF for separate sexes, we did not find any sex-related differences in the movement patterns at any of the three sites. With sexes pooled together, the IPF slope was significantly steeper for Szentendre than for Tabulova $(\mathrm{p}<0.05)$ or Pouzdrany $(\mathrm{p}<0.05)$, predicting higher probability of reaching larger distances for beetles at the two latter sites. IPF elevation was significantly different between Szentendre and Pouzdrany $(\mathrm{p}<0.05)$.

Daily movements were computed using data on individuals with lifespan five and less days. The average distance covered by individuals of $C$. hungaricus in one day (day-

TABLE 2. Results of fitting the inverse power function (IPF) to the movements of the ground beetle, Carabus hungaricus (Coleoptera: Carabidae) recorded using mark-recapture at three sites in the Czech Republic and Hungary, and predicted probability of individuals moving 50, 100, 200, 500 and $1000 \mathrm{~m}$ for each of the populations studied.

\begin{tabular}{|c|c|c|c|c|c|c|c|c|c|c|c|}
\hline & & $=\ln C(+S F)-9(+S F$ & $\mathrm{R}^{\wedge} 2$ & $\mathrm{~F}$ & df & p-value & $\begin{array}{c}50 \\
(\mathrm{~m})\end{array}$ & $\begin{array}{l}100 \\
(\mathrm{~m})\end{array}$ & $\begin{array}{l}200 \\
(\mathrm{~m})\end{array}$ & $\begin{array}{l}500 \\
(\mathrm{~m})\end{array}$ & $\begin{array}{c}1000 \\
(\mathrm{~m})\end{array}$ \\
\hline Pouzdrany & $\mathrm{M}$ & $\ln I=-1.27( \pm 0.089)-4.16( \pm 0.170) * \ln D$ & 0.826 & 204.350 & 1,43 & $\mathrm{P}<0.00001$ & 0.707 & 0.293 & 0.121 & 0.038 & 0.016 \\
\hline \multirow[t]{2}{*}{$(\mathrm{CZ})$} & $\mathrm{F}$ & $\ln I=-1.29( \pm 0.082)-4.05( \pm 0.147) * \ln D$ & 0.833 & 248.59 & 1,50 & $\mathrm{P}<0.00001$ & 0.822 & 0.337 & 0.138 & 0.042 & 0.017 \\
\hline & $\mathrm{M}+\mathrm{F}$ & $\ln I=-1.43( \pm 0.085)-4.42( \pm 0.144) * \ln D$ & 0.829 & 281.16 & 1,58 & $\mathrm{P}<0.00001$ & 0.868 & 0.323 & 0.120 & 0.032 & 0.012 \\
\hline Tabulova & M & $\ln \mathrm{I}=-1.19( \pm 0.111)-4.71( \pm 0.293) * \ln \mathrm{D}$ & 0.877 & 114.18 & 1,16 & $\mathrm{P}<0.00001$ & 0.319 & 0.140 & 0.061 & 0.021 & 0.009 \\
\hline \multirow[t]{2}{*}{$(\mathrm{CZ})$} & $\mathrm{F}$ & $\ln I=-1.09( \pm 0.127)-3.97( \pm 0.321) * \ln D$ & 0.795 & 73.76 & 1,19 & $\mathrm{P}<0.00001$ & 0.492 & 0.231 & 0.109 & 0.040 & 0.019 \\
\hline & $M+1$ & $\ln I=-1.27( \pm 0.124)-4.69( \pm 0.297) * \ln D$ & 0.820 & 104.59 & 1,23 & $\mathrm{P}<0.00001$ & 0.410 & 0.170 & 0.071 & 0.022 & 0.009 \\
\hline Szentendre & $\mathrm{M}$ & $\ln I=-1.86( \pm 0.225)-7.00( \pm 0.596) * \ln D$ & 0.801 & 68.48 & 1,17 & $\mathrm{P}<0.00001$ & 0.239 & 0.066 & 0.018 & 0.003 & 0.001 \\
\hline \multirow[t]{2}{*}{ (HU) } & $\mathrm{F}$ & $\ln I=-1.79( \pm 0.238)-6.79( \pm 0.661) * \ln D$ & 0.802 & 56.77 & 1,14 & $\mathrm{P}<0.00001$ & 0.241 & 0.070 & 0.020 & 0.004 & 0.001 \\
\hline & $\mathrm{M}+\mathrm{F}$ & $\ln I=-2.04( \pm 0.238)-7.57( \pm 0.621) * \ln D$ & 0.803 & 73.33 & 1,18 & $\mathrm{P}<0.00001$ & 0.229 & 0.056 & 0.014 & 0.002 & 0.001 \\
\hline
\end{tabular}


time movement) was $20.3 \mathrm{~m}$ in Pouzdrany site, $17.5 \mathrm{~m}$ in Tabulova and $8.4 \mathrm{~m}$ in Szentendre.

\section{DISCUSSION}

\section{Study outcome and limitations}

Our study showed that adults of $C$. hungaricus are active and mobile beetles frequently moving for tens to hundreds of meters. Although the short distance movements are the most common, individuals are able to cross distances in magnitude of kilometers as estimated by the IPF as well as demonstrated by the distances covered by individual beetles at Pouzdrany steppe.

For individuals from the three studied populations, the dispersal probability estimates differed in magnitude for distances $>100 \mathrm{~m}$. In our study, the three populations inhabiting three sites were sampled using two sampling designs for three time periods. The sites are covered by similar vegetation, their climate is similar, and their parts inhabited by the beetle have similarly flat relief. We suggest that the sampling design, period, size and spatial arrangement of habitats in different locations were the main factors affecting the estimates for dispersal probability. Linear arrangement of traps in Tabulova and Pouzdrany sites resulted in rather high average distance among traps, while the grid design in Szentendre with low average distance among traps, most likely affected the dispersal probability estimates. Similarly, the applied short sampling period might result lower estimates in the dispersal probability for Tabulova.

Apart from quantifying the dispersal probability estimates of $C$. hungaricus, our results showed how vastly different results could the MRR studies give under rather similar circumstances. Mobility estimates based on the MRR are mostly viewed as a species specific trait. Our results provided illustration that the MRR estimated dispersal probabilities might depend on sampling circumstances such as sampling time and design, or habitat patch size (e.g. Fric et al., 2010; Stevens et al., 2010). We suggest that a standardized sampling design and sampling period eliminate such biases mentioned above.

\section{Movement patterns}

The dispersal estimates for C. hungaricus seem rather high in comparison to results of other studies of ground beetles. For example distance of $2.5 \mathrm{~km}$ was enough to isolate populations of $C$. variolosus (Matern et al., 2008). Skłodowski (2008) observed that Pterostichus niger had a movement range between $40-250 \mathrm{~m}$ in a forest-clearcut area in Poland, and he also noted that this pattern might be explained by the random movement of this species. The daily movements estimated for the three studied populations of $C$. hungaricus are rather high in comparison to results of other MRR studies of ground beetles. For example, daily movements by $C$. cancellatus, $C$. hortensis, $C$. nemoralis and $P$. niger ranged between $2.54-3.69 \mathrm{~m}$ /day (Skłodowski, 2008). On the other hand, our results are fully concordant with movements of $C$. variolosus observed by Drees at al. (2008). Also Rijnsdorp (1980) and Den Boer
(1970) observed that males of $C$. problematicus walked with an average speed of $25 \pm 12 \mathrm{~m}$ per day, while females walked with a speed of $15 \pm 4 \mathrm{~m}$ per day. Other Carabus species moved for 40-200 m per night (Hockmann et al., 1989; Kennedy, 1994; Riecken \& Rath, 1996; Assmann, 1998). It is difficult to estimate, however, whether the differences and similarities in dispersal of various species of ground beetles are attributable to ecology or habitat of individual species, or to variability in study designs.

\section{Dispersal options}

For each site, the dispersal probability estimates are based on a sampling during a single season. C. hungaricus individuals regularly live for more than one year, and some individuals live up 5 years (Bérces \& Elek, 2013). It is also well known that the MRR based mobility estimates tend to substantially underestimate long distance movements of studied organisms (e.g. Smout et al., 2010; Drag et al., 2011; Pe'Er et al., 2013). We may thus expect that the beetles are able to reach habitat patches kilometers away from an occupied patch as long as no migration barriers such as e.g. water course and closed canopy forest (including even narrow lines of such habitat, see Pokluda et al., 2012) occur in between. In the fragmented landscapes of Central European lowlands, such long distance movements are highly unlikely mainly due to the decline in the cover of grasslands and increase in cover of closed forest (e.g. Holusa et al., 2012). Habitat patches suitable for C. hungaricus are sparse, and often isolated by migration barriers (Pokluda et al., 2012). Thus, we suggest that due to the critical status and the limited dispersal abilites of $C$. hungaricus in most countries within its occurrence, the facilitated dispersal might be a proper tool for the ensuring beetles' survival in many parts of their range.

Knowledge of $C$. hungaricus mobility, together with knowledge of its habitat requirements and population biology, is likely to benefit the conservation of this species (Pokluda et al., 2012; Bérces \& Elek, 2013) as well as numerous other endangered flightless grassland species such as Dorcadion species (e.g. Baur et al., 2005).

ACKNOWLEDGEMENTS. This paper is dedicated to the memory of Pavel Pokluda (1985-2012), an outstanding young biologist, who tragically died during fieldwork in Papua New Guinea. We would like to thank Z. Fric and M. Konvička for constructive advices on the manuscript, and D. Hauck and J. Vondráček for assistance in the field. The study and its authors were supported by the Hungarian Academy of Sciences (ZE), Bolyai Research Grant (ZE, grant no.: BO/00045/11/8), by the Agency for Nature Conservation and Landscape Protection of the Czech Republic, and the project Biodiversity of Forest Ecosystems (CZ.1.07/2.3.00/20.0064) co-financed by the European Social Fund and the state budget of the Czech Republic.

\section{REFERENCES}

Assman T. 1998: Bedeutung der kontinuät von lebensräumen für den naturschutz - untersuchungen an waldwohnennden laufKäfer (Colepotera: Carabidae) mit beispielen für methodische ergänzen zur landzeitforschung. - Schr. R. Landschaftspfl. Natursch. 58: 191-214. 
BAgUETTE M. 2003: Long distance dispersal and landscape occupancy in a metapopulation of the cranberry fritillary butterfly. - Ecography 26: 153-160.

Baguette M., Petit S. \& QuÉva F. 2000: Population spatial structure and migration of three butterfly species within the same habitat network: consequences for conservation. - J. Appl. Ecol. 37: 100-108.

Baur B., Coray A., Minoretti N. \& ZschokKe S. 2005: Dispersal of the endangered flightless beetle Dorcadion fuliginator (Coleoptera: Cerambycidae) in spatially realistic landscapes. - Biol. Conserv. 124: 49-61.

BÉrCes S. \& EleK Z. 2013: Overlapping generations can balance the fluctuations in the activity patterns of an endangered ground beetle species: long-term monitoring of Carabus hungaricus in Hungary. - Insect Conserv. Diver. 6: 290-299.

Bérces S., Szél G., KöDöвöcz V. \& Kutasi C. 2008: The distribution, habitat types and nature conservation value of a Natura 2000 beetle, Carabus hungaricus Fabricius, 1792 in Hungary. In Penev L., Erwin T. \& Assmann T. (eds): Back to the Roots or back to the Future? Towards a new Synthesis between Taxonomic, Ecological and Biogeographical Apporaches in Carabidology. Proceedings of the XIII European Carabidologists Meeting, Blagoevgrad. Pensoft Inc., Sofia, pp. 363-372.

Bonte D., van den Borre J. \& Lens L. 2006: Geographical variation in wolf spider dispersal behaviour is related to landscape structure. - Anim. Behav. 72: 655-662.

Bowler D.E. \& Benton T.G. 2005: Causes and consequences of animal dispersal strategies: relating individual behavior to spatial dynamics. - Biol. Rev. 80: 205-225.

Campagne P., Buisson E., Varouchas G., Roche P., Baumel A. \& TATONI T. 2009: Modelling landscape structure constraints on species dispersal with a cellular automaton: Are there convergences with empirical data? - Ecol. Complex. 6: 183-190.

Chiari S., Zauli A., Mazziotta A., Luiselli L., Audisio P. \& CarPANETO G.M. 2013: Surveying an endangered saproxylic beetle, Osmoderma eremita, in Mediterranean woodlands: a comparison between different capture methods. - J. Insect Conserv. 17: $171-181$

Cizek L., Hauck D. \& Pokluda P. 2012: Contrasting needs of grassland dwellers: habitat preferences of endangered steppe beetles (Coleoptera). - J. Insect Conserv. 16: 281-293.

Clobert J., Ims R.A. \& Rousset F. 2004: Causes, mechanisms and consequences of dispersal. In Hanski I. \& Gaggiotti O.E. (eds): Ecology, Genetics, and Evolution of Metapopulations. Elsevier Academic Press, Burlington, MA, pp. 307-336.

David G., Giffard B., Piou D. \& Jactel H. 2013: Dispersal capacity of Monochamus galloprovincialis, the European vector of the pine wood nematode, on flight mills. - J. Appl. Entomol. DOI: $10.1111 /$ jen. 12110

Den Boer P.J. 1970: On the significance of dispersal power for populations of carabid beetles (Coleoptera, Carabidae). - Oecologia 4: 1-28.

Drag L., Hauck D., Pokluda P., Zimmermann K. \& Cizek L. 2011: Demography and dispersal ability of a threatened saproxylic beetle: A mark-recapture study of the Rosalia longicorn (Rosalia alpina). - PLoS One 6: e21345.

Drees C., Matern A. \& Assmann T. 2008: Behavioural patterns of nocturnal carabid beetles determined by direct observations under red-light conditions. In Penev L., Erwin T. \& Assmann T. (eds): Back to the Roots and Back to the Future? Towards a New Synthesis between Taxonomic, Ecological and Biogeographical Approaches in Carabidology. Proceedings of the XIII European Carabidologists Meeting, Blagoevgrad, August 20-24, 2007. Pensoft, Sofia, pp. 1-4.
Dyck H. VAN \& Baguette M. 2005: Dispersal behaviour in fragmented landscapes: Routine or special movements? - Basic Appl. Ecol. 6: 535-545.

EwERs R.M. \& DidHam R.K. 2005: Confounding factors in the detection of species responses to habitat fragmentation. - Biol. Rev. 81: 117.

Fric Z. \& Konvicka M. 2007: Dispersal kernels of butterflies: power-law functions are invariant to marking frequency. Basic Appl. Ecol. 8: 377-386.

Fric Z., Hula V., Klimova M., Zimmermann K. \& Konvicka M. 2010: Dispersal of four fritillary butterflies within identical landscape. - Ecol. Res. 25: 543-552.

Hassall C. \& Thompson D. 2012: Study design and mark-recapture estimates of dispersal: a case study with the endangered damselfly Coenagrion mercuriale. - J. Insect Conserv. 16: $111-120$.

Hill J.K., Thomas C.D. \& Lewis O.T. 1996: Effects of habitat patch size and isolation on dispersal by Hesperia comma butterflies: implications for metapopulation structure. - J. Anim. Ecol. 65: 725-735.

Hockmann P., Schlomberg P., Wallin H. \& Weber F. 1989: Bewegungsmuster und orientierung des laufkäfers Carabus auronitens in einem westfälischen Eichen-Hain-buchen-Wald (Radarbeobachtungen und Rückfangexperimente. - Abh. Westf. Mus. Naturk. 51: 1-71.

Holusa J., Kocarek P., Marhoul J. \& Skokanova H. 2012: Platycleis vittata (Orthoptera: Tettigoniidae) in the northwestern part of its range is close to extinction: is this the result of landscape changes? - J. Insect Conserv. 16: 295-303.

HƯRKA K. 1996: Carabidae of the Czech and Slovak Republics. Kabourek, Zlín, 565 pp.

Jonsell M., Schroeder M. \& Larsson T. 2003: The saproxylic beetle Bolitophagus reticulatus: its frequency in managed forests, attraction to volatiles and flight period. - Ecography 26: 421-428.

KenNEDy P.J. 1994: The distribution and movement of ground beetles in relation to set-aside arable land. In Desender K., Dufréne M., Loreau M., Luff M.L. \& Maelfait J.-P. (eds): Carabid Beetles: Ecology and Evolution. Kluwer, Dordrecht, pp. 439-444.

Koenig W.D., Van Vuren D. \& Hooge P.N. 1996: Detectability, philopatry, and the distribution of dispersal distances in vertebrates. - Trends Ecol. Evol. 11: 514-517.

Maes D., Vanreusel W., Talloen W. \& Van Dyck H. 2004: Functional conservation units for the endangered Alcon Blue butterfly Maculinea alcon in Belgium (Lepidoptera: Lycaenidae). - Biol. Conserv. 120: 229-241.

Matern A., Drees C., Meyer H. \& Assmann T. 2008: Population ecology of the rare carabid beetle Carabus variolosus (Coleoptera: Carabidae) in north-west Germany. J. Insect. Conserv. 12: 591-601.

Oleksa A., Chybicki I.J., Gawroński R., Svensson G.P. \& BurcZYK J. 2013: Isolation by distance in saproxylic beetles increases with niche specialization. - J. Insect. Conserv. 17: 219-233.

Pe'er G., Matsinos Y.G., Johst K., Franz K.W., Turlure C., RadchuK V., Malinowska A.H., Curtis J.M.R., NaujoKaitisLewis I., Wintle B.A. \& Henle K. 2013: A protocol for better design, application, and communication of population viability analyses. - Conserv. Biol. 27: 644-656.

Petit S., Moilanen A., Hanski I. \& Baguette M. 2001: Metapopulation dynamics of the bog fritillary butterfly: Movements between habitat patches. - Oikos 92: 491-500.

Pokluda P., Hauck D. \& CizeK L. 2012: Importance of marginal habitats for grassland diversity: fallows and overgrown tall- 
grass steppe as key habitats of endangered ground-beetle Carabus hungaricus. - Insect Conserv. Diver. 5: 27-36.

R Core Team 2013: R: A Language and Environment for Statistical Computing. $R$ Foundation for Statistical Computing. Vienna, Austria. URL http://www.R-project.org/.

RIECKEN U. \& RATHS U. 1996: Use of radio-telemetry for studying dispersal and habitat use of Carabus coriaceus L. - Ann. Zool. Fenn. 33: 109-116.

RisnSDORP A.D. 1980: Pattern of movement in and dispersal from a Dutch forest of Carabus problematicus Hbst. (Coleoptera, Carabidae). - Oecologia 45: 274-281.

Sander A.C., Purtauf T., Wolters V. \& Dauber J. 2006: Landscape genetics of the widespread ground-beetle Carabus auratus in an agricultural region. - Basic Appl. Ecol. 7: 555-564.

Schultz C.B. 1998: Dispersal behavior and its implications for reserve design in a rare Oregon butterfly. - Conserv. Biol. 12: 284-292.

SKŁodowSKI J. 2008: Carabid beetle movements in a clear-cut area with retention groups of trees. In Penev L., Erwin T. \& Assmann T. (eds): Back to the Roots and Back to the Future? Towards a New Synthesis between Taxonomic, Ecological and Biogeographical Approaches in Carabidology. Proceedings of the XIII European Carabidologists Meeting, Blagoevgrad, August 20-24, 2007. Pensoft, Sofia, pp. 451-467.

Smout S., King R. \& Pomeroy P. 2010: Estimating demographic parameters for capture-recapture data in the presence of multiple mark types. - Environ. Ecol. Stat. 18: 331-347.

Stevens V.M., Turlure C. \& Baguette M. 2010: A meta-analysis of dispersal of butterflies. - Biol. Rev. 85: 625-642.

Szél G., Bérces S., Kutasi C. \& KöDöBöCz V. 2006: A magyar futrinka (Carabus hungaricus Fabricius, 1792) hazai elterjedése és élöhelyei. [Distribution and habitats of Carabus hungaricus Fabricius, 1792 in Hungary (Coleoptera: Carabidae.)] - Praenorica Folia Hist.-Natur. 9: 45-80 [in Hungarian].

Thiele H.U. 1977: Carabid Beetles in their Environments. A Study on Habitat Selection by Adaptation in Physiology and Behaviour. Springer, Berlin, 369 pp.

Ulrich W. \& ZalewsKi M. 2007: Are ground beetles neutral? Basic Appl. Ecol. 8: 411-420.

Zimmermann K., Fric Z., Jiskra P., Kopeckova M., Vlasanek P., Zapletal M. \& Konvicka M. 2011: Mark-recapture on large spatial scale reveals long distance dispersal in the Marsh Fritillary, Euphydryas aurinia. - Ecol. Entomol. 36: 499-510.

Received December 16, 2013; revised and accepted April 18, 2014 Prepublished online September 10, 2014 